DOI: https://doi.org/10.32836/2521-666X/2020-70-15

УДК 336. 658.14

Пухальська Н.О.

викладач фрінансово-економічних дисциплін, Ірпінський державний коледж економіки та права

Болдова А.А.

кандидат педагогічних наук,

доцент кафедри фрінансових ринків,

Університет державної фріскальної служби України

Болдова Ю.А.

здобувач вищої освіти другого (магістерського) рівня,

Університет державної фіскальної служби України

Pukhalska Nataliia

Irpin state College of Economics and Law

Boldova Antonina, Boldova Yuliia

University of the State Fiscal Service of Ukraine

ФІНАНСОВІ КОРПОРАЦІЇ ТА ЇХ ВПЛИВ НА ЕКОНОМІКУ УКРАЇНИ

\title{
FINANCIAL CORPORATIONS AND THEIR INFLUENCE ON THE ECONOMY OF UKRAINE
}

Стаття узагальнює дані щзодо ролі, значення та особливостей діяльності фінансових корпорацій на фінансовому ринку України, висвітлює фінансову діагностику й оцінку їх фінансового стану. Означено сучасні тенденції роботи фінансових корпорачій та перспективи залучення коштів іноземних фінансових компаній для інвестування у вітчизняний ринок фінансових послуг. Визначено, шзо для сприяння економічному зростанню, досягнення иілей зовнішньоекономічної політики $i$ все більшої інтеграчії України необхідно укріпляти механізми залучення коштів вітчизняних та іноземних фінансових корпорацій в украйнську економіку. Окреслено аспекти вітчизняного законодавства та необхідність адаптачії його до міжнародних законодавчих норм. Виявлено низку проблем інтеграції іноземних фінансових корпорачій на вітчизняний ринок фінансових послуг, передумов стимулювання економічної привабливості України для іноземних інвесторів та пріоритетних напрямів удосконалення податкового законодавства, щзо потребують подальшого вивчення.

Ключові слова: фінансові корпоращії, фінансова діяльність, міжнародні фінансові відносини, фінансовий стан, передовий досвід, глобалізація, адаптація, розвиток фінансової сфери, розвиток фінансового ринку.

Статья обобщает данные о роли, значении и особенностях деятельности финансовых корпораций на финансовом рынке Украины, освещает финансовую диагностику и оиенку их финансового состояния. Обозначены современные тенденции работы финансовых корпоращий и перспективы привлечения средств иностранных финансовых компаний для инвестирования в отечественный рынок финансовых услуг. Определено, что для содействия экономическому росту, достижения целей внешнеэкономической политики и все больщей интеграции Украины необходимо укреплять механизмы привлечения средств отечественных и иностранных финансовых корпораций в украинскую экономику. Очерчены аспекты отечественного законодательства и необходимость адаптачии его к международным законодательным нормам. Выявлен ряд проблем интеграции иностранных финансовых корпоращий на отечественный рынок финансовых услуг, предпосылок стимулирования экономической привлекательности Украины для иностранных инвесторов и приоритетных направлений усовершенствования налогового законодательства, которые требуют дальнейшего изучения.

Ключевые слова: финансовые корпорачии, финансовая деятельность, международные финансовые отношения, финансовое состояние, передовой опьтт, глобализация, адаптация, развитие финансовой сферы, развитие финансового рынка.

The article summarizes the role, importance and features of financial corporations in the financial market of Ukraine, highlights the financial diagnosis and assessment of their financial condition and identifies such a necessary aspect of further development as attracting funds from creditors, depositors and investors need them as an additional source. Also, the article outlines information on the main aspect of the activities of financial corporations, which is based on corporate expansion and mergers and acquisitions of other firms. At the same time, it is reflected that the monitoring, diagnostics and assessment of the financial condition of the corporation as the only process, the mechanism of which allows implementing effective management decisions, is becoming relevant. The effectiveness of these decisions will identify the financial condition of the corporation to forecast further management. The article identifies current trends in financial corporations and prospects for attracting funds from foreign financial companies to invest in the domestic financial services market. A brief analysis of the activities of the largest financial companies in the world that provide financial services in Ukraine and characterized the profitability indicators. It is also determined that in order to promote economic growth, achieve the goals of foreign economic policy and increasing integration of Ukraine, there is an objective need to strengthen mechanisms for attracting funds from domestic and foreign financial corporations in the Ukrainian economy. Aspects of domestic legislation and the need to adapt it to international law are outlined. A number of problems of integration of foreign financial corporation's into the domestic market of financial services, preconditions for stimulating Ukraine economic attractiveness for foreign investors and priority areas for improving tax 
legislation that need further study have been identified. The article also reveals that the study offorms and types of corporate expansion in the global financial services market, analysis of various methods of financial and economic condition of the company and diagnosis of financial condition corporations is given much attention, but the issue of increasing the influence of international companies on the national financial market processes of trans nationalizations economic Ukraine.

Key words: financial corporations, financial activity, international financial relations, financial condition, best practices, globalization, adaptation, development of the financial sphere, development of the financial market.

Постановка проблеми. Фінансові корпорації як реальні суб'єкти міжнародних фінансових відносин своєю діяльністю посилюють процес інтеграції країн, що розвиваються, в систему міжнародних фінансових зв'язків. Це зумовлює збільшення фінансових потоків між країнами та посилення міжнародних економічних зв'язків.

Передовий досвід розвинутих країн світу переконливо доводить переваги використання фінансів корпорацій, що забезпечують збереження високої фінансової ефективності, позитивно впливають на життєвий рівень населення та стабільність політичної системи.

Для сучасної економіки України залучення коштів вітчизняних та іноземних фінансових корпорацій може виступити дієвим механізмом для визначення нових пріоритетів економічного зростання й досягнення цілей зовнішньоекономічної політики. Глобальні тенденції залучення та розподілу капіталу міжнародних корпорацій поставили їх у центр світового економічного розвитку. Проте проблема збільшення впливу міжнародних компаній та поглиблення процесів транснаціоналізації економіки України залишається актуальною.

Актуальність досліджуваної тематики зумовлена необхідністю залучення коштів вітчизняних та іноземних фінансових корпорацій в українську економіку задля сприяння економічному зростанню та досягненню цілей зовнішньоекономічної політики.

Аналіз останніх досліджень і публікацій. Означена тема опрацьована в багатьох наукових публікаціях. Зокрема, здійснено дослідження терміна «корпорація», форм корпоративної експансії на світовому ринку фінансових послуг, проведено аналіз різних методик фінансово-господарського стану компанії та діагностику фінансового стану корпорацій.

Слід виокремити публікації Е. Альтмана, В. Бівера, О. Богдановича, А. Ван Горна, В. Віннікової, Н. Дєєвої, П. Друкера, У. Кінга, Г. Кірейцева, К.Р. Макконела, М. Мальської, М. Назарової, В. Небрата, А. Олійника, О. Подцерковного, В. Потія, Т. Тоффлера, І. Шульги, В. Яцури.

Глобальні тенденції залучення та розподілу капіталу міжнародних корпорацій поставили останніх у центр світового економічного розвитку. Проте проблема збільшення впливу міжнародних компаній та поглиблення процесів транснаціоналізації економіки України залишається актуальною.

Мета статті полягає у розгляді та узагальненні деяких даних, зокрема аналітичних, щодо діяльності представників міжнародних фінансових корпорацій на території України, розгляді проблем, наявних у означеній сфері, та вивченні можливих перспектив їх подальшого розвитку на вітчизняному ринку фінансових послуг.

Виклад основного матеріалу. Фінансові корпорації перебувають у центрі фінансових систем передових країн світу, спрямовуючи кошти від кредиторів, вкладників та інвесторів до тих учасників фінансового ринку, які потребують додаткових коштів. Нині значна частина коштів спрямовується через фінансові корпорації, при цьому за власниками вільних ресурсів зберігається безпосередня можливість здійснювати фінансування напряму (наприклад, домогосподарства, що надають позики підприємству). Вкладники можуть розміщувати свої кошти в банку, щоб скористатися вищою ліквідністю депозиту або придбати акції інвестиційного фонду як зручний спосіб диверсифікувати свої активи. Навіть якщо вкладники купують цінні папери на фондовому ринку, вони, як правило, використовують брокера цінних паперів або інші так звані фінансові допоміжні компанії. Також проводиться аналіз ролі фінансових корпорацій у різних типах економіки, їх розвиток та сприяння сталому розвитку.

Варто відзначити, що сьогодні фінансові корпорації виступають домінуючою організаційно-правовою формою на ринку фінансових послуг майже в усіх країнах світу. В основу діяльності фінансових корпорацій покладено корпоративну експансію, яка проявляється у «злитті та поглинанні» інших фірм.

Механізми оцінки та ефективності діяльності фінансової корпорації підпорядковані досягненню іiі стратегічної мети. Результати такого оцінювання дають змогу встановити масштаб і зміну спрямування в управлінні діяльністю компанії, прогнозувати їх вплив на ii ключові функціональні підсистеми, схвалювати відповідні управлінські рішення щодо підвищення та підтримки рівня ефективності управління діяльністю, вибирати методи, способи, інструменти управління діяльністю компанії [3].

Водночас фінансову діагностику та оцінку фінансового стану корпорації можна розглядати як єдиний процес, реалізація якого дає змогу впроваджувати ефективні управлінські рішення. Як наслідок, за допомогою фінансової діагностики можна не тільки відслідковувати стан компанії на кожному часовому проміжку, але й ідентифікувати іiі фінансовий стан для здійснення подальшого управління [3].

Сучасна тенденція роботи фінансових корпорацій показує, що значна частина коштів спрямовується через фінансові корпорації, при цьому за власниками коштів зберігається безпосередня можливість здій- 
снювати фінансування напряму (наприклад, домогосподарства, що надають позики підприємству). Вкладники також можуть розміщувати свої кошти в банку, щоб скористатися вищою ліквідністю депозиту або придбати акції інвестиційного фонду як зручний спосіб диверсифікувати свої активи. Навіть якщо вкладники купують цінні папери на фондовому ринку, вони, як правило, використовують брокера цінних паперів або інші так звані фінансові допоміжні компанії [3].

Нижче наведено перелік топ-10 найбільших фінансових корпорацій у світі та розмір їх доходу станом на 2019 рік за даними американського фінансово-економічного журналу «Форбс» [2].

Проаналізувавши перелік найбільших фінансових компаній світу, бачимо, що він включає ті компанії, які надають фінансові послуги на території України. Хоча перелік таких компаній на українському ринку фінансових послуг налічує невелику кількість представництв міжнародних фінансових компаній, це дає можливість інтегрування України у глобальну систему надання фінансових послуг.

У табл. 2 наведено показники загального та чистого річного доходу фінансових установ станом на 2019 рік.

Як можна побачити 3 табл. 2, всі вибрані компанії є прибутковими, а річний дохід від будь-якої діяльності перевищує двадцять мільйонів гривень. 3 огляду на це, згідно зі ст. 134 Податкового кодексу України (далі ПКУ), компанії зобов'язані визначати об'єкт оподаткування з ПнП шляхом коригування фінансового результату до оподаткування на усі різниці, визначені відповідно до положень ПКУ.
Проаналізувавши фінансову звітність вибраних компаній, доходимо висновку, що вони є активними агентами фінансового ринку, адже здійснюють інвестиційну, страхову та банківську діяльність, в результаті якої генерують прибуток та розподіляють його між учасниками компанії, застосовуючи такий механізм, як дивідендні платежі та відповідні ставки податку до них, згідно з розділом ІІІ ПКУ.

Щодо перспективи залучення коштів іноземних фінансових компаній, то Стратегією розвитку фінансового сектору України до 2025 року від 28 травня 2019 року, затвердженою Національним банком України, Національною комісією з цінних паперів та фондового ринку, Національною комісією, що здійснює державне регулювання у сфері ринків фінансових послуг, Фондом гарантування вкладів фізичних осіб та Міністерством фінансів України, задля сприяння кредитуванню вітчизняної економіки передбачено такі кроки:

- підтримка кредитування малих та середніх підприємств;

- адаптація до застосування в Україні квазікапітальних інструментів міжнародних фінансових організацій;

- стимулювання кредитування підприємств АПК, зокрема фермерських господарств, під заставу землі;

- зменшення перешкод для іпотечного кредитування;

- стимулювання експорту;

- стимулювання розвитку ринку небанківського кредитування;

Таблиця 1

Дохід топ-10 фінансових корпорацій у світі (млн. дол. США)

\begin{tabular}{|c|l|c|c|c|c|}
\hline № & \multicolumn{1}{|c|}{ Назва компанії } & Сфера діяльності & Дохід & Чистий дохід & $\begin{array}{c}\text { Країна } \\
\text { походження }\end{array}$ \\
\hline 1 & Berkshire Hathaway & Багатофункціональна & 247,5 & 4,02 & США \\
\hline 2 & Ping An Group & Страхові послуги & 163,597 & 16,237 & Китай \\
\hline 3 & Allianz & Страхові послуги & 143,86 & 8,49 & Німеччина \\
\hline 4 & AXA & Страхові послуги & 113,13 & 2,31 & Франція \\
\hline 5 & JP Morgan Chase & Банківські послуги & 105,486 & 30,709 & США \\
\hline 6 & ICBC & Банківські послуги & 105,4 & 44,26 & Китай \\
\hline 7 & China Construction Bank & Банківські послуги & 94,987 & 37,2 & Китай \\
\hline 8 & China Life & Страхові послуги & 92,71 & 22,04 & Китай \\
\hline 9 & Bank of America & Банківські послуги & 91,24 & 28,14 & США \\
\hline 10 & Agricultural Bank of China & Банківські послуги & 87,6 & 29,5 & Китай \\
\hline
\end{tabular}

Джерело: складено авторами на основі узагальнення даних джерела [2]

Таблиця 2

Загальний та чистий дохід представництв міжнародних фінансових компаній в Україні станом на 2019 рік (тис. грн.)

\begin{tabular}{|l|c|c|c|}
\hline \multicolumn{1}{|c|}{ Назва компанії } & Загальний дохід & $\begin{array}{c}\text { Податок на прибуток } \\
\text { підприємств }\end{array}$ & Чистий дохід \\
\hline ПАТ “Crédit Agricole” & $2,114,230$ & 384,299 & $1,729,931$ \\
\hline AT «Сбербанк» & 461,729 & 19,912 & 441,817 \\
\hline Deutsche Bank & 455,558 & 14,886 & 440,672 \\
\hline Міжнародна CK “MetLife” & 251,046 & 56,661 & 194,385 \\
\hline
\end{tabular}

Джерело: складено авторами на основі узагальнення даних джерел [1; 4; 7; 10$]$ 
- розбудова інфраструктури для ефективного управління проблемними активами [10].

Як можна побачити, одним із напрямів застосування в Україні інструментів міжнародних фінансових організацій є адаптація до застосування в Україні інструментів міжнародних фінансових організацій.

Вплив фінансових корпорацій та їх глобалізаційну діяльність варто розглядати як перспективу збільшення фінансової спроможності інвестиційного ринку та посилення конкурентного середовища в банківському та страховому секторах. Більш того, за останні два десятиліття в результаті фінансової лібералізації та подолання економічних і політичних бар'єрів міжнародні фінансові групи продемонстрували високу активність на фінансових ринках країн, що розвиваються. Серед таких країн можна виокремити Естонію, Болгарію, Чехію, Словаччину, де іноземні компанії займають $75-85 \%$ фінансового ринку [5; 6].

Узагальнивши низку наукових досліджень та врахувавши думку іноземних компаній, доходимо висновку, що головними перешкодами для інвестування у вітчизняний ринок фінансових послуг для іноземних компаній є такі:

- посилений тиск з боку контролюючих органів, як наслідок, зростаюче податкове навантаження на компанію;

- високий рівень корупції;

- економічні та політичні нестабільності та невизначеності в країні [6].

Ці факторі не сприяють залученню іноземних капіталів у внутрішній фінансовий сектор та в економіку України загалом. Враховуючи тенденції сучасного світу, провідні фінансові компанії сприяють розвитку та зростанню світової галузі фінансових послуг. Очікується, що до 2022 року валовий прибуток галузі фінансових послуг досягне майже 26,5 трильйонів доларів США. Однак, незважаючи на те, що нові інвестори неохоче здійснюють вкладення у фінансовий ринок України, частка фінансових установ $з$ іноземним капіталом істотно не змінилась і навіть продовжує прямувати до зростання, що свідчить про те, що наявні інвестори продовжують фінансувати свої дочірні компанії в Україні, хоча обсяги фінансування набагато нижчі від тих, що здійснюються в інших країнах світу.
Висновки. Підсумовуючи вищевикладене, доходимо висновку, що на українському ринку фінансових послуг здійснюють свою діяльність чотири компанії, які являють собою представництва міжнародних фінансових груп. Три 3 цих компаній $є$ незалежними та фінансово стійкими. Це, звісно, прискорює процес інтегрування України у глобальну систему надання фінансових послуг, але низка негативних факторів стримує активний розвиток означеної сфери.

Подолання цих перешкод створить сприятливу фінансову атмосферу для діяльності фінансових корпорацій, оскільки аналіз вказує на те, що навіть у сучасних умовах всі названі представники міжнародних фінансових груп на українському ринку фінансових послуг мають позитивний фінансовий результат до оподаткування та розподіляють чистий згенерований прибуток між власниками компаній за допомогою такого репатріаційного механізму, як дивідендні платежі, застосовуючи ставки, передбачені ПКУ.

Пріоритетом також $є$ інтеграція України до системи міжнародних валютно-фінансових відносин, які потенційно можуть принести багато позитивних результатів. Для досягнення цієї мети необхідно розвиватись та прямувати до ефективної ринкової інфраструктури, адекватної регуляторної політики та сприятливого макроекономічного середовища інвестиційної привабливості України для іноземних фінансових компаній. Саме тому актуальності набуває адаптація положень вітчизняного законодавства 3 питань платіжних послуг до вимог актів Свропейського Союзу.

Слід зауважити, що Україна поступово інтегрується до міжнародних фінансових ринків, а наслідки глобалізаційних процесів стають дедалі відчутнішими для української фінансової системи. Для більш позитивного спрямування вектору глобалізаційних змін слід приділити увагу розвитку вітчизняного законодавства та адаптації до міжнародних законодавчих норм. Проблеми інтеграції іноземних фінансових корпорацій на ринок вітчизняних фінансових послуг, передумови стимулювання економічної привабливості України для іноземних інвесторів та пріоритетні напрями удосконалення податкового законодавства потребують подальшого вивчення.

\section{Список літератури:}

1. Фінансова звітність та звіт незалежного аудитора за рік, що закінчився 31 грудня 2019 року / Deutsche Bank. 2020. URL: https://www.db.com/ukraine/docs/Annual_financial_statements_under_IFRS_for_2019.pdf (дата звернення: 01.11.2020).

2. Top 10 Largest Finance Companies in the World in 2020, Financial Services Industry Factsheet. Business magazine "Forbes". 2020. URL: https://www.forbes.com/global2000/\#5458f845335d (дата звернення: 01.11.2020).

3. Understanding Financial Accounts, Chapter "The role of financial corporations in the financial system". OECD Publishing. 2017. URL: https://read.oecd-ilibrary.org/economics/understanding-financial-accounts_978926 4281288-en\#page3 (дата звернення: 03.11.2020).

4. Фінансова звітність та звіт незалежного аудитора за рік, що закінчився 31 грудня 2019 року / АТ «Сбербанк». 2020. URL: file://C:/Users/admin/Downloads/IFRS\%20FS\%20SBRF_2019.pdf (дата звернення: 03.11.2020).

5. Болдова А., Бреус К., Вітренко Л. Інтеграція ринку фінансових послуг у глобалізоване світове середовище. Збірник наукових праць Наиіонального університету державної податкової служби України. 2013. № 2. С. 6-13. URL: http://nbuv.gov.ua/j-pdf/znpnudps_2013_2_3.pdf (дата звернення: 03.11.2020). 
6. Манюк Н. Особливості оподаткування банківських установ в Україні. International Scientific Journal. 2016. № 1. С. 66-69.

7. Олійник А. Міжнародні фінансові організації як складова фінансової глобалізації. Міжнародні відносини та всесвітня економіка. 2017. URL: https://otherreferats.allbest.ru/international/00844260_0.html (дата звернення: 04.11.2020).

8. Фінансова звітність та звіт незалежного аудитора за рік, що закінчився 31 грудня 2019 року / ПАТ “Сrédit Agricole". 2020. URL: https://credit-agricole.ua/storage/files/cab-2019-fin-part-ukr.pdf (дата звернення: 03.11.2020).

9. Фінансова звітність та звіт незалежного аудитора за рік, що закінчився 31 грудня 2019 року / ПАТ «Метлайф». 2020. URL: https://www.metlife.ua/content/dam/metlifecom/ua/PDFs/financialreports/2019/2019_Financials_ audited_report.pdf (дата звернення: 03.11.2020).

10. Стратегія розвитку фінансового сектору України до 2025 року / Національний банк України. 2019. URL: https://bank.gov.ua/ua/about/develop-strategy (дата звернення: 07.11.2020).

1. Deutsche Bank (2020) Finansova zvitnist' ta zvit nezalezhnoho audytora za rik, shcho zakinchyvsya 31 hrudnya 2019 roku [Financial statements and independent auditor's report for the ended year 31 desember 2019]. Available at: https://www.db.com/ukraine/docs/Annual_financial_statements_under_IFRS_for_2019.pdf (accessed 01 November 2020).

2. Top 10 Largest Finance Companies in the World in 2020. (2020). Financial Services Industry Factsheet. Business magazine "Forbes". Available at: https://www.forbes.com/global2000/\#5458f845335d (accessed 01 November 2020).

3. Understanding Financial Accounts, Chapter "The role of financial corporations in the financial system" (2017). OECD Publishing. Available at: https://read.oecd-ilibrary.org/economics/understanding-financial-accounts_9789 264281288-en\#page3 (accessed 03 November 2020).

4. AT “Sberbank" (2020) Finansova zvitnist' ta zvit nezalezhnoho audytora za rik, shcho zakinchyvsya 31 hrudnya 2019 roku [Financial statements and independent auditor's report for the ended year 31 desember 2019 y.]. Available at: file://C:/Users/admin/Downloads/IFRS\%20FS\%20SBRF_2019.pdf (accessed 03 November 2020).

5. Boldova A. (2013) Intehratsiya rynku finansovykh posluh u hlobalizovane svitove seredovyshche [Intrgration of financical services market into the globalised world environment]. Zb. naukovykh prats' Natsional'noho universytetu derzhavnoyi podatkovoyi sluzhby Ukrayiny. Elektronne naukove fahove vydannya. No. 2, pp. 6-13. Available at: http://nbuv.gov.ua/j-pdf/znpnudps_2013_2_3.pdf.

6. Manyuk N. (2016) Osoblyvosti opodatkuvannya bankivs'kykh ustanov v Ukrayini. [Features of taxation of banking institutions in Ukraine]. International Scientific Journal, no. 1, pp. 66-69.

7. Oliynyk A. (2017) Mizhnarodni finansovi orhanizatsiyi yak skladova finansovoyi hlobalizatsiyi. [International financial organizations as a component of financial globalization]. Mizhnarodni vidnosyny ta vsesvitnya ekonomika. Available at: https://otherreferats.allbest.ru/international/00844260_0.html (accessed 04 November 2020).

8. PAT "Crédit Agricole" (2020) Finansova zvitnist' ta zvit nezalezhnoho audytora za rik, shcho zakinchyvsya 31 hrudnya 2019 roku [Financial statements and independent auditor's report for the ended year 31 desember 2019 ]. Available at: https://credit-agricole.ua/storage/files/cab-2019-fin-part-ukr.pdf (accessed 03 November 2020).

9. PAT "Metlayf" (2020) Finansova zvitnist' ta zvit nezalezhnoho audytora za rik, shcho zakinchyvsya 31 hrudnya 2019 roku [Financial statements and independent auditor's report for the ended year 31 desember 2019 y]. Available at: https://www.metlife.ua/content/dam/metlifecom/ua/PDFs/financialreports/2019/2019_Financials_audited_report.pdf (accessed 03 November 2020).

10. Stratehiya rozvytku finansovoho sektoru Ukrayiny do 2025 roku (2019) Natsional'nyy bank Ukrayiny. Available at: https://bank.gov.ua/ua/about/develop-strategy (accessed 07 November 2020). 